\title{
"Cytochrome c oxidase I DNA sequence of Camponotus ants with different nesting strategies is a tool for distinguishing between morphologically similar species"
}

\author{
Manuela O. F. Ramalho' ${ }^{1}$ Rodrigo M. Santos ${ }^{2} \cdot$ \\ Tae T. Fernandes ${ }^{2} \cdot$ Maria Santina C. Morini $^{2}$. \\ Odair C. Bueno ${ }^{1}$
}

Received: 18 October 2015/ Accepted: 18 May 2016/Published online: 25 May 2016

(C) Springer International Publishing Switzerland 2016

\begin{abstract}
The great diversity of Camponotus, high levels of geographic, intraspecific and morphological variation common to most species of this genus make the determination of the interspecific limits of Camponotus a complex task. The Cytochrome c oxidase 1 (COI) gene was sequenced in this study to serve as an auxiliary tool in the identification of two taxa of Camponotus thought to be morphologically similar. Additionally, characteristics related to nesting were described. Five to fifteen workers from twenty-one colonies were analyzed, collected from twigs scattered in the leaf litter and from trees located in different regions of Brazil. Phylogenetic reconstructions, haplotype network, and nesting strategies confirmed the existence of two species and that they correspond to Camponotus senex and Camponotus textor. Our results emphasize that the COI can be used as an additional tool
\end{abstract}

Manuela O. F. Ramalho

manuramalho2010@gmail.com

Rodrigo M. Santos

santosrml@gmail.com

Tae T. Fernandes

taetf@hotmail.com

Maria Santina C. Morini

mscmorini@gmail.com

Odair C. Bueno

odaircb@rc.unesp.br

1 Biologia, CEIS, Universidade Estadual Paulista "Júlio de Mesquita Filho" (UNESP), Campus Rio Claro, Av. 24A, 1515, Bela Vista, Rio Claro, SP 13506-900, Brazil

2 Biologia, NCA, Universidade de Mogi das Cruzes (UMC), Campus de Mogi das Cruzes, Av. Dr. Cândido Xavier de Almeida Souza, 200, Centro Cívico, Mogi das Cruzes, SP 08780-911, Brazil for the identification of morphologically similar Camponotus species.

Keywords Atlantic forest - Brazilian savannah · Leaf litter . Tree vegetation - Twigs

\section{Introduction}

Camponotus Mayr 1861 is cosmopolitan, and it is currently the most diverse genus of ants with more than 1000 described species, subspecies and varieties (Bolton 2015). The genus is not monophyletic (Brady et al. 2000), and the high degree of variation in morphological characters makes taxonomy extremely complex and challenging (Garcia et al. 2013).

Camponotus ants have a preferentially nocturnal habit and generalist diet (Yamamoto and Del-Claro 2008). They may exhibit mutualism with cochineals, aphids and leafhoppers and feed on extrafloral nectaries (Hölldobler and Wilson 1990). Some species prey on herbivorous insects (Del-Claro et al. 1996) and honeybees (Akre and Hansen 1990), and they may destroy wooden frameworks and electrical installations in urban environments (Bueno and Campos-Farinha 1999).

Camponotus species live in a variety of habitats and microhabitats; colonies may be polygynous, and nests are built in interstices or on the ground, in twigs or rotten twigs (Fernandes et al. 2012; Souza et al. 2012; Matta et al. 2013). They can nest in trees using silk produced by the larvae to weave nests (Santos and Del-Claro 2009). Many species build secondary or satellite nests in different environments (Bueno and Campos-Farinha 1999; Matta et al. 2013). This feature is another challenge to the biological characterization of the species because these nests are related to different functions (Lanan et al. 2011). 
In Brazil, the genus is recorded in a wide variety of native vegetation, including the Cerrado (Brazilian savannah) (Oliveira and Brandão 1991; Del-Claro and Oliveira 2000), the Brazilian Atlantic Domain (Delabie et al. 2000; Mentone et al. 2011; Suguituru et al. 2013), the Amazon Rainforest (Vasconcelos and Delabie 2000) and the Caatinga (tropical dry forest) (Ulysséa and Brandão 2013), as well as in agricultural areas (Marinho et al. 2002). However, the great morphological similarity among many species of the genus immensely complicates their accurate identification (Ronque et al. 2015); thus, many of the studies which refer to species of Camponotus are limited to listing morphotypes or reasonably distinguishable forms.

C. senex (Smith 1858) and C. textor (Forel 1899) are examples of morphologically similar species. Smith (1858), when describing $C$. senex from material from Brazil, did not mention the use of silk for nest building. Forel (1879) studied specimens derived from the Cordoba, Mexico, collection and noted the morphological similarity with $C$. senex and the presence of silk in the nest. In 1899 , Forel described specimens from Costa Rica, including $C$. senex textor, and mentioned the presence of silk. However, in 1905, after analyzing specimens from Brazil, the author concluded that they corresponded to $C$. senex and reported that the nests were built with silk. Wheeler (1915) perpetuated the association between $C$. senex and nests that included silk and was followed by Wheeler and Wheeler (1953), Schremmer (1979) and Hölldobler and Wilson (1983, 1990). Longino (2006) analyzed the morphology of specimens from Costa Rica and separated $C$. senex textor into $C$. senex and $C$. textor. This author reported that only $C$. textor has larvae that produce silk and describes some ecological aspects and nesting strategies specific to $C$. senex and $C$. textor. Nevertheless, doubts persisted because Robson et al. (2015) recently referred to C. senex as having silk-producing larvae when comparing the behavior of this species with that of Dendromyrmex during nest building.

Studies have demonstrated the efficiency of the COI method for identifying species (Silva-Brandão et al. 2009), especially those considered morphologically similar (Ronque et al. 2015). The method is based on the fact that, throughout evolutionary history, DNA sequences have accumulated mutations that make them unique to each species (Hebert et al. 2003).

"A high quality faunal inventory and a refined taxonomy are essential prerequisites for understanding the ecological processes of ecosystems" (Silva et al. 2015). Therefore, in this study, we present the results of molecular and phylogenetic analysis of a segment of the mitochondrial gene cytochrome oxidase 1 (COI) as well as a description of biological aspects related to the nesting of two morphologically similar species of Camponotus.

\section{Materials and methods}

\section{Characterization of collection areas and nests}

Nests were collected from trees and twigs scattered on the leaf litter (Fig. 1; Table 1) of fragments of the Atlantic Forest and the Brazilian savannah vegetation (Colombo and Joly 2010) (Fig. 2). The twigs with colonies of Camponotus were measured (length and diameter), and the adult and immature (egg + larvae) individuals were counted. The colonies on twigs scattered on the leaf litter were named Group I (GenBank accession code: KT364225-KT364233), and the colonies on canopy trees, Group II (GenBank accession code: KM37004-KM371011).

\section{DNA extraction and genetic characterization of COI}

The worker ants collected were stored in a freezer at $-20{ }^{\circ} \mathrm{C}$ for DNA extraction. Five workers were analyzed from each colony found on twigs scattered in the leaf litter. For those in trees, fifteen workers were analyzed per colony. The difference in the number of workers subjected to molecular analysis is related to the size of the populations of the colonies on twigs and trees.

Total DNA was extracted after macerating the tissues in a lysis solution (100 mM Tris, pH 9.1, $100 \mathrm{mM} \mathrm{NaCl}$, $50 \mathrm{mM}$ EDTA, $0.5 \%$ SDS). Subsequently, proteinase K was added to the samples, which were then incubated at $55{ }^{\circ} \mathrm{C}$ for $3 \mathrm{~h}$. The protein residue was precipitated with $5 \mathrm{M} \mathrm{NaCl}$, and the supernatant was washed with 100 and $70 \%$ alcohol for DNA precipitation. The material was dried for $10 \mathrm{~min}$ in a Thermo Savant DNA 120 SpeedVac ${ }^{\circledR}$, and the DNA was resuspended in TE (10 mM Tris, $1 \mathrm{mM}$ EDTA, pH 8).

The mitochondrial gene Cytochrome c oxidase 1 (COI) was amplified using the GoTaq ${ }^{\circledR}$ Flexi DNA Polymerase Kit (Promega, Madison, WI, USA). The specific primers for Camponotus, CampR and CampF (Ramalho et al. 2016) were used for COI amplification, since the universal primers did not work. The PCR occurred under the following conditions: $94{ }^{\circ} \mathrm{C}$ for $5 \mathrm{~min}$, followed by 35 cycles at $94{ }^{\circ} \mathrm{C}$ for $1 \mathrm{~min}, 48^{\circ} \mathrm{C}$ for $1.5 \mathrm{~min}$ and $68^{\circ} \mathrm{C}$ for $2.5 \mathrm{~min}$, with a final extension at $65{ }^{\circ} \mathrm{C}$ for $7 \mathrm{~min}$. The samples were purified with the kits GFX PCR and Gel Band Purification (GE Healthcare) and quantified in a NanoDrop 2000 spectrophotometer (Thermo Scientific). Sequencing reactions used the BigDye Terminator kit (V.3.1) (Applied Biosystems). Amplicons were sequenced in both directions in a 3130 Genetic Analyzer automated sequencer (Applied Biosystems).

The consensus sequences obtained in this work for each colony were edited manually using the program BioEdit 
Fig. 1 Arboreal nest (a) with workers and larvae on the external (b) and internal parts (c); Camponotus worker leaving a hole on twigs scattered in the leaf litter (d)
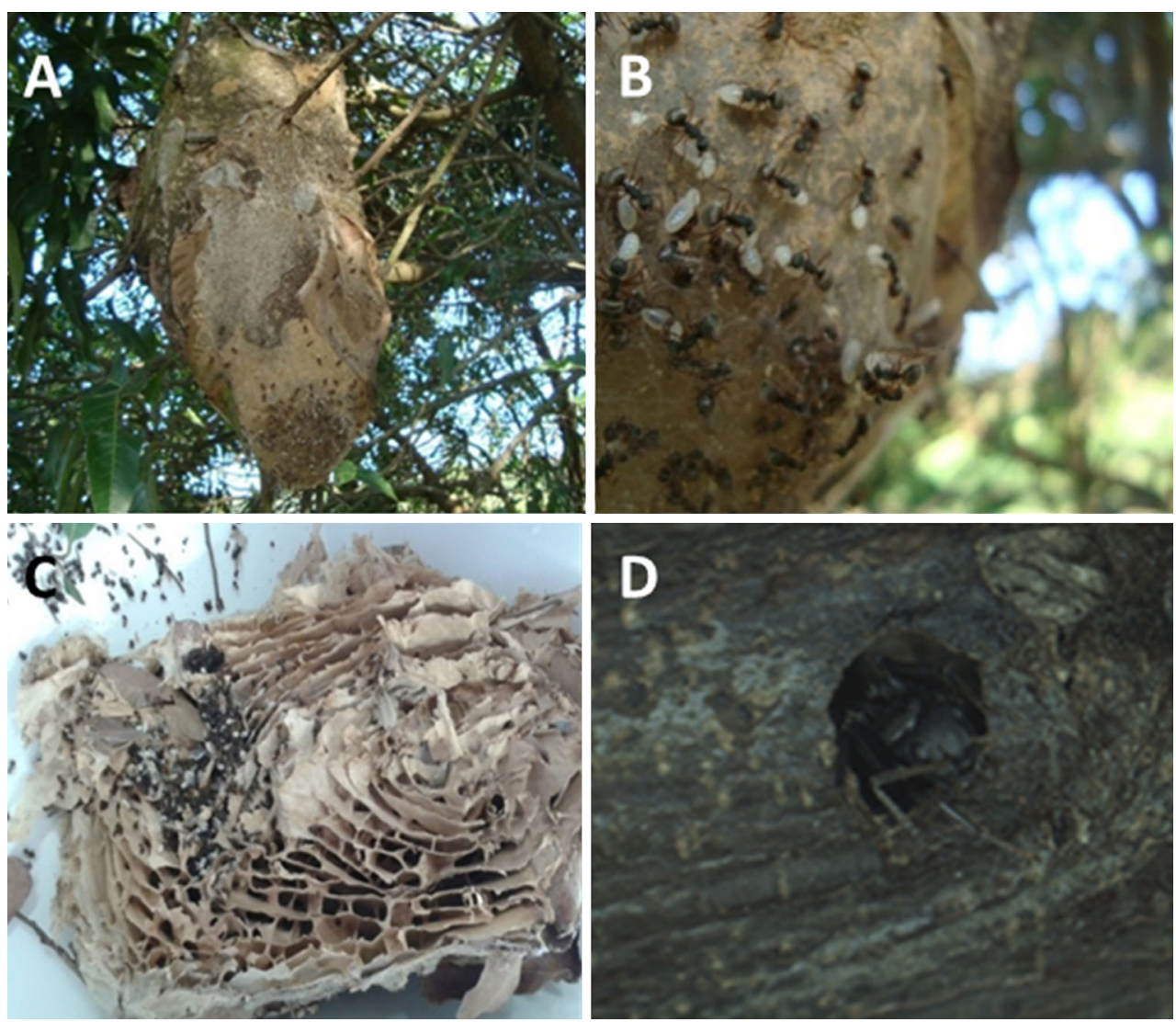

Table 1 Structure and total number of nests according to the collection localities

\begin{tabular}{lll}
\hline Nest & Total number & City/State \\
\hline Structure & 1 & São Paulo/São Paulo \\
In hollow galleries of twigs scattered in the leaf litter. (Group I) & 4 & Itaquaquecetuba/São Paulo \\
& 2 & Suzano/São Paulo \\
\hline In trees. The nest is made up of leaves intertwined with silk. (Group II) & 1 & Araraquara/São Paulo \\
& 1 & Ilheús/Bahia \\
& 1 & Ribeirão Preto/São Paulo \\
& 1 & Rio Claro/São Paulo \\
& 1 & São João da Boa Vista/São Paulo \\
& 1 & Santa Rita do Passa Quatro/São Paulo \\
& 2 & Uberlândia/Minas gerais \\
\hline
\end{tabular}

Sequence Alignment Editor (Hall 1999) and aligned with the Clustal W tool (Thompson et al. 1994). Consensus sequences were confirmed as coding sequences using the ORF Finder (Open Reading Frame Finder) of the NCBI (http://www.ncbi.nlm.nih.gov/) and compared with sequences deposited in GenBank using BLASTn. Taxa with $\geq 85 \%$ similarity to our consensus sequences were selected as outgroups for phylogenetic reconstructions.
Phylogenetic analyses of maximum parsimony were performed using the software PAUP 4.0 (Swofford 1998) with heuristic search parameters and 1000 bootstrap replicates. The TN93 + L sequence evolution model was chosen as the best model for maximum likelihood analysis under the Akaike Information Criterion. The analysis was performed in MEGA 6.6 (Tamura et al. 2013) using nearest-neighbor interchange (NNI) and 1000 bootstrap 


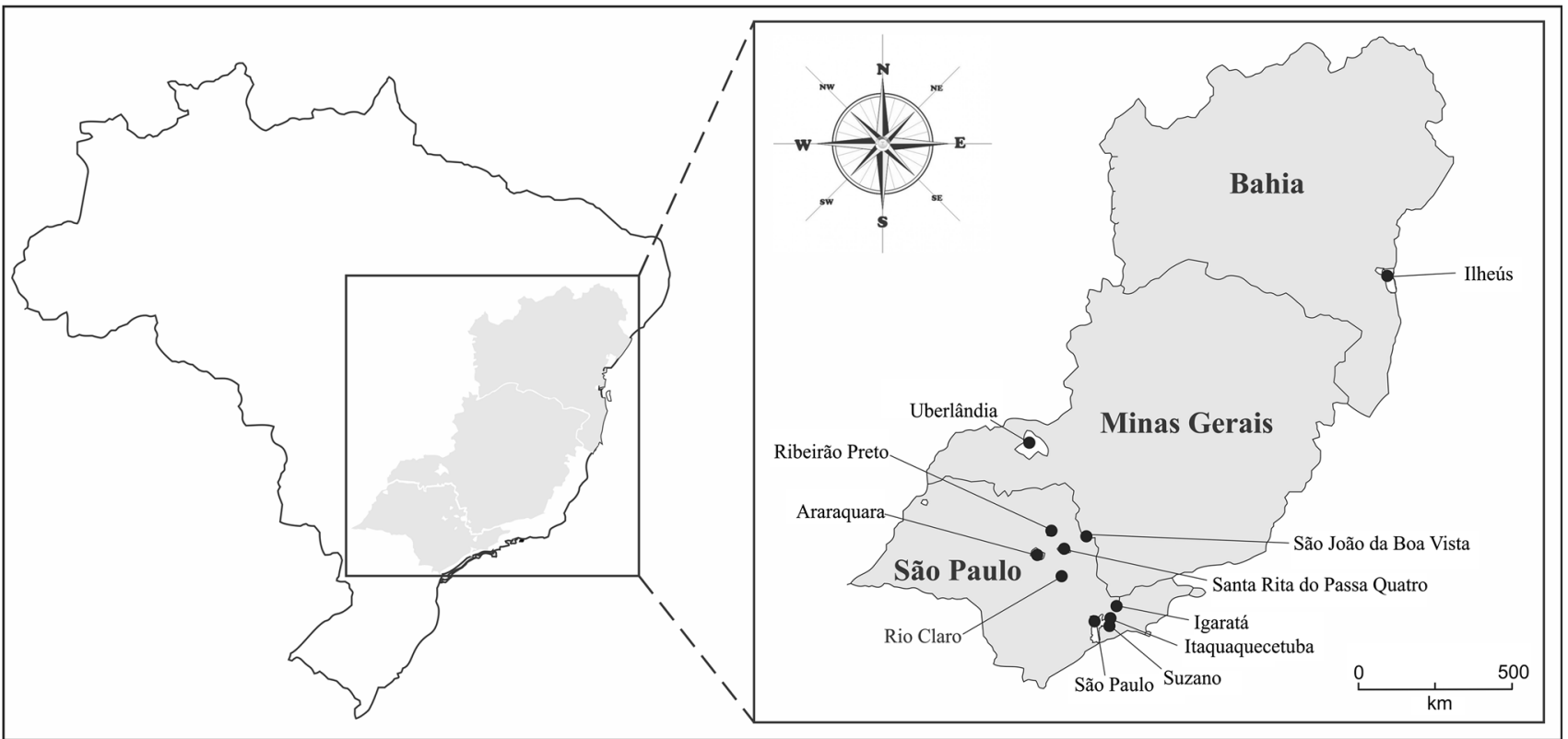

Fig. 2 Geographical location of the collection areas of Camponotus nests in three Brazilian states

replicates. The genetic distance of worker ants from Camponotus colonies was calculated using the APE package (Paradis et al. 2004) under the Kimura 2-parameter (K2P) (Kimura 1980) and the rgdal package (Bivand et al. 2013) of the software R (R Core Team 2015). The haplotype network was generated with the median-joining method using Network 4510 (Bandelt et al. 1999).

The all specimens used (belonging to the group I and group II; Table 1) were identified according to Longino (2006), and confirmed by Dr. Rodrigo Machado Feitosa (Federal University of Paraná) and Dr. Jacques Hubert Charles Delabie (State University of Santa Cruz and Cocoa Research Center). The specimens are deposited in the reference collection at the University of Mogi das Cruzes (see Suguituru et al. 2015) and the Executive Committee of the Cocoa Farming Plan (Comissão Executiva do Plano da Lavoura Cacaueira-CEPLAC) collection.

\section{Results}

The consensus sequences in Group I were found in twigs within fragments of native Atlantic Forest vegetation present in urban parks (Table 1; Fig. 1d). The twigs measured from $11.05 \pm 0.45$ to $35.99 \pm 4.77 \mathrm{~mm}$ in diameter and 35 to $22.3 \mathrm{~cm}$ in length. The colonies had 12 to 138 workers and 3 to 73 immature individuals. Nests from Group II were suspended in trees (Table 1; Fig. 1a) located at the edge of native Atlantic Forest or savannah vegetation fragments. The number of workers and/or immature individuals exceeded 100 (Fig. 1b, c). These our results add new information to the literature on nest characteristics.

Consensus sequences fragments were obtained for $464 \mathrm{bp}$ of the COI gene. Three different haplotypes were present in Group I and five in Group II; there were 59 polymorphic sites between the both groups $(12.71 \%)$, yielding the haplotype network (Fig. 3). The haplotype diversity $(h)$ was 0.639 and 0.857 for Group I and Group II, respectively. In Group I, the haplotype H_1 grouped workers from the cities of Suzano and Igaratá, H_2 grouped workers coming from the municipalities of Itaquaquecetuba and Suzano and H_3 had workers from the city of São Paulo (Table 2). In Group II, we found five distinct haplotypes. The haplotype H_4 grouped consensus sequences of workers from Rio Claro and Uberlândia; the H_5 haplotype grouped those from São João da Boa Vista and Santa Rita do Passa Quatro; and haplotypes H_6, H_7 and $\mathrm{H} \_8$ represented the workers from Ilhéus, Araraquara and Ribeirão Preto, respectively (Table 2).

For phylogenetic reconstruction, the following GenBank sequences were selected to form the outgroup: $C$. castaneus (Latreille 1802); C. americanus (Mayr 1862); and $C$. quadrinotatus (Forel 1886). Oecophylla smaragdina (Fabricius 1775) was added because it also belongs to the subfamily Formicinae and shows weaving behavior. Odontomachus laticeps (Roger 1861) has plesiomorphic characteristics compared with the other ants (see Moreau et al. 2006). The phylogenetic hypotheses obtained (Maximum Likelihood and Maximum Parsimony, Fig. 4a, b, respectively) show, with high support values, both groups 


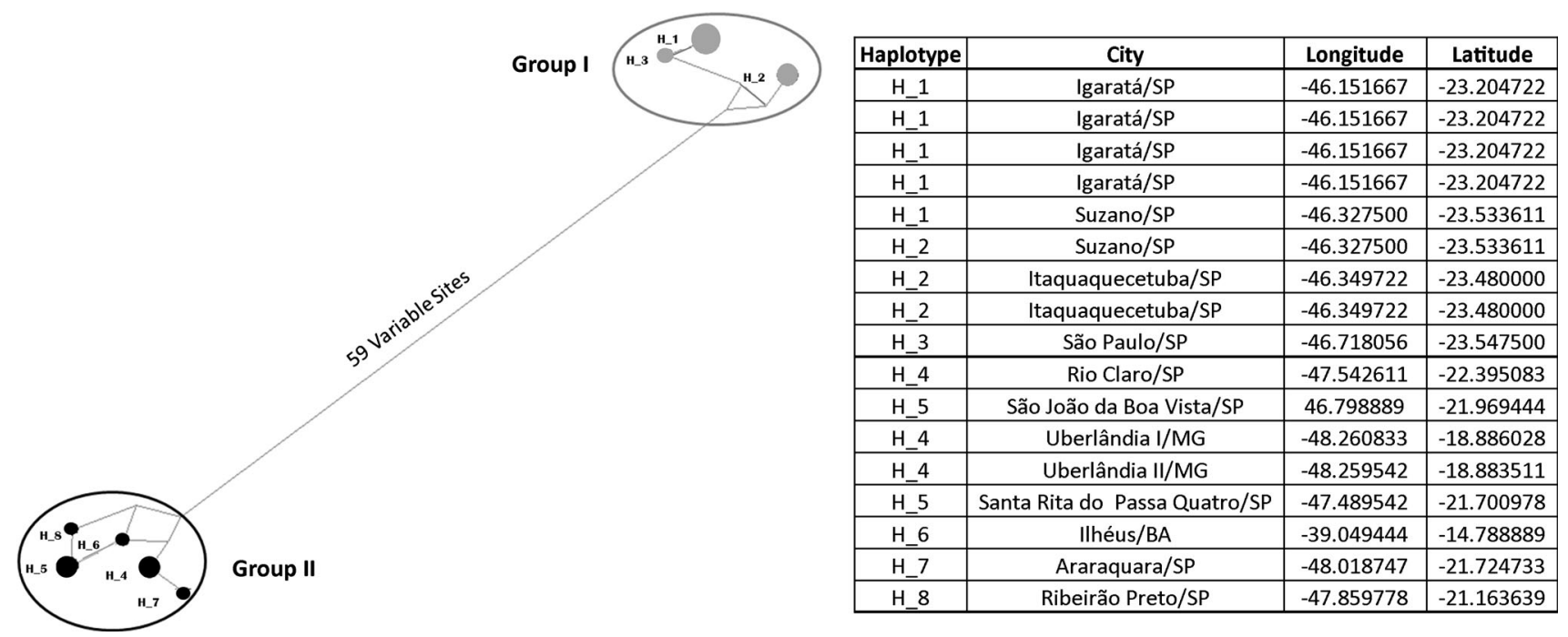

Fig. 3 Haplotype network analysis of workers that nest on twigs (Group I-gray circle) and trees (Group II-black circle). (Color figure online)

Table 2 Pairwise comparison of p-distances between haplotypes of Camponotus with different nesting habits. H_1 to H_3 of Camponotus recorded in twigs scattered in the leaf litter, and $\mathrm{H} \_4$ to $\mathrm{H} \_8$ are haplotypes of Camponotus recorded in arboreal nests

\begin{tabular}{l|llllllll} 
& H_1 & H_2 & H_3 & H_4 & H_5 & H_6 & H_7 & H_8 \\
\hline H_1 & IIIII & & & & & & & \\
H_2 & 0.010897181 & IIIII & & & & & \\
H_3 & 0.00216456 & 0.008699375 & IIIII & & & & \\
H_4 & 0.157508047 & 0.151496404 & 0.154634476 & IIIII & & & & \\
H_5 & 0.160398229 & 0.154345415 & 0.157508047 & 0.006521832 & IIIII & & & \\
H_6 & 0.157508047 & 0.151496404 & 0.154634476 & 0.004338422 & 0.002164506 & IIIII & & \\
H_7 & 0.160398229 & 0.154345415 & 0.157508047 & 0.002164506 & 0.008714818 & 0.006521832 & IIIII & \\
H_8 & 0.157508047 & 0.151496404 & 0.154634476 & 0.008714818 & 0.002164506 & 0.004338422 & 0.010917464 & IIIII
\end{tabular}

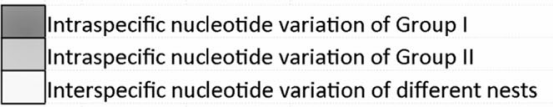

H_7 0.1603982290 .1543454150 .1575080470 .0021645060 .0087148180 .006521832

\begin{tabular}{l|l|lll} 
H__ & 0.1575080470 .151496404 & 0.154634476 & 0.0087148180 .002164506 & 0.0043384220 .010917464
\end{tabular}

as monophyletic and the individuals from Group II most closely related to $C$. quadrinotatus. C. americanus and $C$. castaneus, chosen for the outgroup, were also sister groups and thus, despite the relatively low support for the major relationships between these groups of species, we can demonstrate that the colonies of Group I and Group II consist of distinct and monophyletic taxonomic units.

\section{Discussion}

The phylogenetic hypothesis that we obtained, associated with the genetic distances and haplotype diversity data, allows us to conclude that the Camponotus workers belong to two distinct species. These results, together with observations of the nesting habits of the workers in Groups I and II and the morphological characteristics proposed by Longino (2006), show that the colonies located in twigs scattered in the leaf litter (Group I) belong to C. senex. The colonies hanging from trees in nests formed by leaves interspersed with silk (Group II) belong to C. textor. These observations corroborate the description and identification based on morphological characters described by Longino (2006). But, they do not support the suggestion that the two species should be merged into a single one (Mackay 2004). It is important to clarify that this work has not performed extensive phylogenetic study of Camponotus, however mitotypes were still grouped in two a monophyletic clade with strong support: Group I (C. senex) and Group II (C. textor). A large study involving all subfamilies of Camponotus and several genes could help reveal the phylogenetic relationships of this diverse group.

Nests of $C$. senex are common in moist environments, from mature forest to anthropogenically disturbed sites (Longino 2006). In this study, we found that C. senex nested only in urban parks composed of native forest. Extensive surveys were conducted of twigs scattered in the leaf litter of the Atlantic Forest (Fernandes et al. 2012) and in a Eucalyptus forest with developed understory (Souza et al. 2012), and no C. senex nests were observed. Nests of C. textor were observed in the canopy of tropical forests (Longino 2006), and in our study, we found them in trees 


\section{A}

Oecophylla smaragdina (DQ353382)

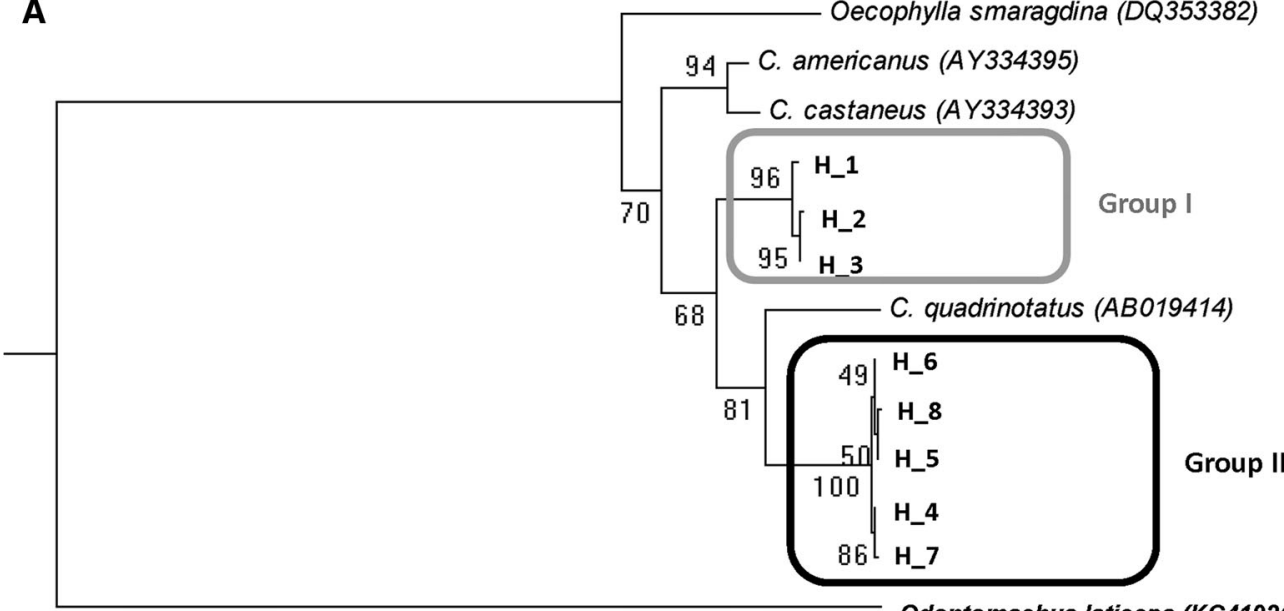

Odontomachus laticeps (KC419215)
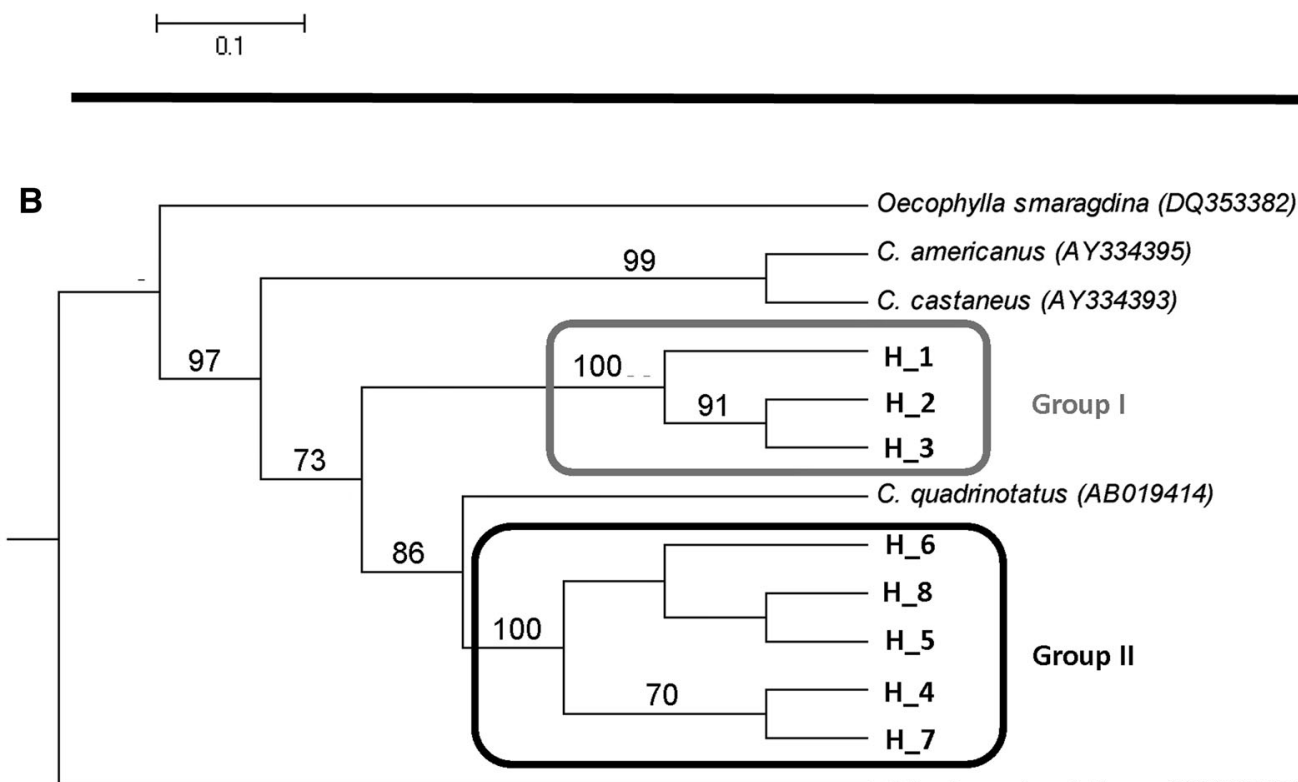

Fig. 4 Phylogenetic analysis with Maximum Likelihood and Maximum Parsimony (both showing boostrap support) of Camponotus that nest on twigs dispersed in the litter (Group I) and tree (Group II) obtained using mitochondrial DNA. a Single tree inferred under

of the Atlantic Forest and savannah vegetation, either anthropogenically disturbed or not. There is also no record of workers of these species foraging on the vegetation of areas located in the Atlantic Domain of the Brazilian Southeast region (Morini et al. 2006; Munhae et al. 2009; Suguituru et al. 2015). The few reports available indicate that there is no habitat overlap between $C$. senex and $C$. textor and this information was not previously described in the literature.

These arboreal species of Camponotus differ in the size of their nests; those of $C$. senex are much smaller than those of $C$. textor. The populations found inside twigs scattered in the leaf litter are relatively small because the maximum likelihood search shown with branch lengths proportional to estimated divergence with a TN93 $+\mathrm{G}$ model of sequence evolution. b Cladogram tree with boostrap support values. Sequences obtained from GenBank were added in these analysis

space is limited (Hölldobler and Wilson 1990). C. senex probably occupies twigs previously drilled by wood-boring insects (Longino 2006; Powell 2013), including C. renggeri (Ronque et al. 2015). Myrmelachista spp. (Nakano et al. 2012, 2013) and Pseudomyrmex phyllophilus (Ketterl et al. 2003) are also arboreal species whose colonies may be found on twigs on the ground of the study areas, but in these cases, the twigs probably housed the colony before falling into the leaf litter.

For many species of arboreal ants, fallen twigs in the leaf litter represent an ephemeral shelter or satellite nests containing workers and immature individuals, and this may be the case for $C$. senex. The existence of satellite nests 
increases the chances for territory defense, protection of the host plant and survival of the colony itself, which, when concentrated in one place, is at increased risk of predation (Santos and Del-Claro 2009). This behavior is relatively common among ants (Debout et al. 2007) and may also be the case for $C$. textor. During our expeditions, we observed more than one nest per tree or nests in trees that were very close to each other.

By comparison, twigs scattered in the leaf litter may be considered structurally simpler nests and require low investment by ants to occupy them, and many species of Camponotus make use of this type of structure (Ronque et al. 2015; Jiménez-Soto and Philpott 2015). The species quickly occupy these nests (Jiménez-Soto and Philpott 2015) but also move more frequently looking for new places to nest (Byrne 1994; McGlynn 2012). However, this seems not to be the case for $C$. textor, which suspends the nests in trees and constructs them with leaves intertwined with silk, making them comparatively more stable structures.

These biological characteristics associated with the genetic divergence of $12.71 \%$ between $C$. senex and $C$. textor allow us to conclude that they are actually two distinct species. For Hymenoptera, COI sequence divergence generally ranges from 8 to $16 \%$ (Hebert et al. 2003). In addition to interspecific divergence, intraspecific differences were also detected for the two species. C. textor shows greater genetic variation than $C$. senex. However, the colonies of $C$. senex were collected from geographically close localities, allowing greater gene flow and reduced genetic variation (McGlynn 2012). Furthermore, these results may be interpreted as support for the molecular separation of the species because, despite the high genetic variation among $C$. textor workers, all the populations studied were securely associated with the same species. The intraspecific divergence was less than $3 \%$, which, for ants, has been considered insufficient variation for recognizing distinct species (Smith et al. 2005).

Although recent studies have demonstrated the importance of COI in species identification (Ojha et al. 2014; Paknia et al. 2015; Smith et al. 2015), the delimitation of a species is very complex for the information contained in only one gene to be considered (Green 1996). The use of this technique should be associated with environmental, behavioral and morphological characteristics, as demonstrated by Ronque et al. (2015), Darienko et al. (2015) and Gomes et al. (2015). That is, a COI should be used as an additional tool, especially in hyperdiverse groups, including Camponotus (Smith et al. 2005). Thus, our results reinforce the assumption that different approaches in the process of delimitation of a species are essential when analyzing in an integrated fashion. We hope that the results presented here will assist in the correct identification of these species of Camponotus, especially in biodiversity studies, and encourage new integrative studies in an attempt to delineate potentially problematic taxa.

Acknowledgments The authors thank Dr. Kleber Del-Claro (Federal University of Uberlândia) for the help in collecting arboreal nests; Dr. Rodrigo Machado Feitosa (Federal University of Paraná, Paraná) and Dr. Jacques Hubert Charles Delabie (State University of Santa Cruz and Cocoa Research Center, Bahia), for the morphological identification of the species (Voucher \#5692); FAPESP (process no. 2013/16861-5), CNPq (process no. 302363/2012-2) and CAPES Foundation (process no. 007343/2014-00), for their financial support; and SISBIO (case no. 45492) for the collecting license.

\section{References}

Akre RD, Hansen LD (1990) Management of carpenter ants. In: Meer RKV, Jaffe K, Cedeno A (eds) Applied myrmecology-a world perspective. Westview Press, San Francisco, pp 693-700

Bandelt HJ, Forster P, Röhl A (1999) Median-joining networks for inferring intraspecific phylogenies. Mol Biol Evol 16:37-48

Bivand R, Keitt T, Rowlingson B, Pebesma M, Summer M (2013) rgdal: bindings for the geospatial data abstraction library. $\mathrm{R}$ package version, 1

Bolton B (2015) An online catalog of the ants of the world. http:// antcat.org. Accessed Sep 2015

Brady SG, Gadau J, Ward PS (2000) Systematics of the ant genus Camponotus (Hymenoptera: Formicidae): a preliminary analysis using data from the mitochondrial gene cytochrome oxidase I. In: Austin $\mathrm{AD}$, Dowton $\mathrm{M}$ (eds) Hymenoptera. Evolution, Biodiversity and Biological Control. CSIRO Publishing, Collingwood, Victoria, pp 131-139

Bueno OC, Campos-Farinha AEC (1999) Formigas Urbanas: estratégias de controle. Vetores and Pragas 2:5-7

Byrne MM (1994) Ecology of twig-dwelling ants in a wet lowland tropical forest. Biotropica 1:61-72

Colombo AF, Joly CA (2010) Brazilian Atlantic forest lato sensu: the most ancient Brazilian forest, and a biodiversity hotspot, is highly threatened by climate change. Braz J Biol 70:697-708

Darienko T, Gustavs L, Eggert A, Wolf W, Pröschold T (2015) Evaluating the species boundaries of green microalgae (Coccomyxa, Trebouxiophyceae, Chlorophyta) Using integrative taxonomy and DNA barcoding with further implications for the species identification in environmental samples. Plos One 10(6): 0127838

Debout G, Schatz B, Elias M, Mckey D (2007) Polydomy in ants: what we know, what we think we know, and what remains to be done. Biol J Linn Soc 90:319-348

Delabie JHC, Agosti D, Nascimento IC (2000) Litter ant communities of the brazilian Atlantic rain forest region. In: Agosti D, Majer JD, Alonso LE, Schultz T (eds) Sampling ground-dwelling ants: case studies from world's rain forests, vol 18. Curtin University School of Environmental Biology Bulletin, Perth, pp 1-17

Del-Claro K, Oliveira PS (2000) Conditional outcomes in a neotropical treehopper-ant association: temporal and species-specific variation in ant protection and Homopteran fecundity. Oecologia 124:156-165

Del-Claro K, Berto V, Réu W (1996) Effect of herbivore deterrence by ants on the fruit set of an extrafloral nectary plant, Qualea multiflora (Vochysiaceae). J Trop Ecol 12:887-892

Fabricius, JC (1775) Systema entomologiae, sistens insectorum classes, ordines, genera, species, adiectis synonymis, locis, descriptionibus, observationibus. Kortii, Flensbvrgi et Lipsiae 30: 832 
Fernandes TT, Silva RR, Souza DR, Araújo N, Morini MSC (2012) Undecomposed twigs in the leaf litter as nest-building resources for ants (Hymenoptera: Formicidae) in areas of the Atlantic Forest in the southeastern region of Brazil. Pysche. doi:10.1155/ 2012/896473

Forel A (1879) Études myrmécologiques en 1879 (deuxième partie [1re partie en 1878]). Bulletin de la Société Vaudoise des Sciences Naturelles 16:53-128

Forel A (1886) Études myrmécologiques en 1886. Annales de la Société Entomologique de Belgique 30:131-215

Forel A (1899) Formicidae. Biologia Centrali-Americana Hymenoptera 3:1-169

Garcia FH, Wiesel E, Fischer G (2013) The ants of Kenya (Hymenoptera: Formicidae)-faunal overview, first species checklist, bibliography, accounts for all genera, and discussion on taxonomy and zoogeography. J East Afr Nat Hist Soc 101:127-222

Gomes LC, Pessali TC, Sales NG, Pompeu PS, Carvalho DC (2015) Integrative taxonomy detects cryptic and overlooked fish species in a neotropical river basin. Genetica 143:581-588

Green DM (1996) The bounds of species: hybridization in the Bufo americanus group of North American toads. Israel J Zool 42:95-109

Hall TA (1999) BioEdit: a user-friendly biological sequence alignment editor and analysis program for Windows 95/98/NT. In: Nucleic acids symposium series pp 95-98

Hebert PD, Cywinska A, Ball SL (2003) Biological identifications through DNA barcodes. Proc R Soc Lond B Biol Sci 270:313-321

Hölldobler B, Wilson EO (1983) The evolution of communal nestweaving in ants. Am Sci 71:490-499

Hölldobler B, Wilson EO (1990) The Ants. Harvard University Press, Cambridge

Jiménez-Soto E, Philpott SM (2015) Size matters: nest colonization patterns for twig-nesting ants. Ecol Evol 5:3288-3298

Ketterl J, Verhaagh M, Bihn JH, Brandão CRF, Engels W (2003) Spectrum of ants associated with Araucaria angustifolia trees and their relations to hemipteran trophobionts. Stud Neotrop Fauna E 38:199-206

Kimura M (1980) A simple method for estimating evolutionary rates of base substitutions through comparative studies of nucleotide sequences. J Mol Evol 16:111-120

Lanan MC, Dorhaus A, Bronstein JL (2011) The function of polydomy: the ant Crematogaster torosa preferentially forms new nests near food sources and fortifies outstations. Behav Ecol Sociobiol 65:959-968

Latreille PA (1802) Histoire naturelle des fourmis, et recueil de mémoires et d'observations sur les abeilles, les araignées, les faucheurs, et autres insectes, vol 16. Impr. Crapelet, Paris, p 445

Longino JT (2006) New species and nomenclatural changes for the Costa Rican ant fauna (Hymenoptera: Formicidae). Myrmecol Nachr 8:131-143

Mackay WP (2004) The systematic and biology of the new world carpenter ants of the hyperdiverse genus Camponotus (Hymenoptera: Formicidae). http://www.utep.edu/leb/antgenera. htm. Accessed 4 Sep 2015

Marinho CG, Zanetti R, Delabie JH, Schlindwein MN, Ramos LDS (2002) Diversidade de formigas (Hymenoptera: Formicidae) da serapilheira em eucaliptais (Myrtaceae) e área de cerrado de Minas Gerais. Neotrop Entomol 31:187-195

Matta SLS, Morini MSC, Hilsdorf AWS (2013) Genetic relationship among Camponotus rufipes Fabricius (Hymenoptera: Formicidae) nests by RAPD molecular markers. Acta Sci Biol Sci 35:89-92

Mayr G (1861) Die europäischen Formiciden. Nach der analytischen Methode bearbeitet. C. Gerolds Sohn, Wien, p 80
Mayr G (1862) Myrmecologische Studien. Verhandlungen der Kaiserlich-Königlichen Zoologisch-Botanischen Gesellschaft in Wien 12:649-776

McGlynn TP (2012) The ecology of nest movement in social insects. Annu Rev Entomol 57:291-308

Mentone TO, Diniz EA, Munhae CB, Bueno OC, Morini MSC (2011) Composição da fauna de formigas (Hymenoptera: Formicidae) de serapilheira em florestas semidecídua e de Eucalyptus spp., na região sudeste do Brasil. Biota Neotrop 11. ID Artigo: bn00511022011

Moreau CS, Bell CD, Vila R, Archibald SB, Pierce NE (2006) Phylogeny of the ants: diversification in the age of angiosperms. Science 312:101-104

Morini MSDC, Kamazuka N, Leung R, Suguituru SS, Da Silva LF (2006) Ant fauna (Hymenoptera: Formicidae) in Magnoliophyta native to the Atlantic Forest. Sociobiology 47:433-444

Munhae CB, Bueno ZAFN, Morini MSC, Silva RR (2009) Composition of the ant fauna (Hymenoptera: Formicidae) in public squares in southern Brazil. Sociobiology 53:455-472

Nakano MA, Feitosa RM, Moraes CO, Adriano LDC, Hengles EP, Longui EL, Morini MSC (2012) Assembly of Myrmelachista Roger (Formicidae: Formicinae) in twigs fallen on the leaf litter of brazilian Atlantic Forest. J Nat Hist 46:2103-2115

Nakano MA, Miranda VFO, Souza DRD, Feitosa RM, Morini MSC (2013) Occurrence and natural history of Myrmelachista Roger (Formicidae: Formicinae) in the Atlantic forest of southeastern Brazil. Rev Chil Hist Nat 86:169-179

Ojha R, Jalali SK, Ali TM, Venkatesan T, Prosser SW, Kumar NK (2014) DNA barcoding of Indian ant species based on cox1 gene. Indian J Biotechnol 13:165-171

Oliveira PS, Brandão CRF (1991) The ant community associated with extrafloral nectaries in the Brazilian cerrados. In: Huxley CR, Cutler DF (eds) Ant-plant interactions. Oxford Univ. Press, Oxford, pp 198-212

Paknia O, Bergmann T, Hadrys H (2015) Some 'ant'swers: application of a layered barcode approach to problems in ant taxonomy. Mol Ecol Resour. doi:10.1111/1755-0998.12395

Paradis E, Claude J, Strimmer K (2004) APE: analyses of phylogenetics and evolution in R language. Bioinformatics 20:289-290

Powell S (2013) The role of beetles produced cavities as filter on the assembly of arboreal ant communities. In: XXI Simpósio de Mirmecologia, Fortaleza

R Core Team (2015) R: A language and environment for statistical computing. Vienna, Austria. http://www.R-project.org

Ramalho MO, Martins C, Silva LMR, Martins VG, Bueno OC (2016) Molecular profile of the brazilian weaver ant Camponotus textor Forel, 1899 (Hymenoptera, Formicidae). Neotropical Entomol. doi:10.1007/s13744-016-0392-Z

Robson SK, Kohout RJ, Beckenbach AT, Moreau CS (2015) Evolutionary transitions of complex labile traits: silk weaving and arboreal nesting in Polyrhachis ants. Behav Ecol Sociobiol 69:449-458

Roger J (1861) Die Ponera-artigen Ameisen (Schluss). Berliner Entomologische Zeitschrift 5:1-54

Ronque MU, Azevedo-Silva M, Mori GM, Souza AP, Oliveira OS (2015) Three ways to distinguish species: using behavioural, ecological, and molecular data to tell apart two closely related ants, Camponotus renggeri and Camponotus rufipes (Hymenoptera: Formicidae). Zool J Linn Soc-Lond. doi:10.1111/ zoj. 12303

Santos JC, Del-Claro K (2009) Ecology and behaviour of the weaver ant Camponotus (Myrmobrachys) senex. J Nat Hist 43:1423-1435

Schremmer F (1979) Die nahezu unbekannte neotropische Weberameise Camponotus (Myrmobrachys) senex (Hymenoptera: Formicidae). Entomol Gen 5:363-378 
Silva RR, Silvestre R, Brandão CRF, Morini MSC, Delabie JHC (2015) Grupos tróficos e guildas em formigas poneromorfas. Poneromorfas do Brasil, In: Simpósio de Mirmecologia, Ilhéus 155-171

Silva-Brandão KL, Lyra ML, Freitas AVL (2009) Barcoding Lepidoptera: current situation and perspectives on the usefulness of a contentious technique. Neotropical Entomol 38:441-451

Smith F (1858) Catalogue of hymenopterous insects in the collection of the British Museum. Part VI. Formicidae. London: British Museum 216

Smith MA, Fisher BL, Hebert PD (2005) DNA barcoding for effective biodiversity assessment of a hyperdiverse arthropod group: the ants of Madagascar. Philos Trans R Soc B 360:1825-1834

Smith MA, Janzen DH, Hallwachs W, Longino JT (2015) Observations of Adelomyrmex (Hymenoptera: Formicidae) reproductive biology facilitated by digital field microscopy and DNA barcoding. Can Entomol 147:611-616

Souza DR, Fernandes TT, Nascimento JRO, Suguituru SS, Morini MSC (2012) Characterization of ant communities (Hymenoptera: Formicidae) in twigs in the leaf litter of the Atlantic rainforest and Eucalyptus trees in the southeast region of Brazil. Pysche. doi:10.1155/2012/532768

Suguituru SS, Souza DRD, Munhae CDB, Pacheco R, Morini MSDC (2013) Diversidade e riqueza de formigas (Hymenoptera: Formicidae) em remanescentes de Mata Atlântica na Bacia Hidrográfica do Alto Tietê, SP. Biota Neotrop 13:1-8

Suguituru SS, Morini MSC, Feitosa RM, Silva RS (2015) Formigas do Alto Tietê. São Paulo, Canal6 450. http://canal6.com.br/ formigas/. Accessed Sep 2015
Swofford D (1998) PAUP 4.0: phylogenetic analysis using parsimony. Smithsonian Institution

Tamura K, Stecher G, Peterson D, Filipski A, Kumar S (2013) MEGA6: molecular evolutionary genetics analysis version 6.0. Mol Biol Evol 30:2725-2729

Thompson JD, Higgins DG, Gibson TJ (1994) CLUSTAL W: improving the sensitivity of progressive multiple sequence alignment through sequence weighting, position-specific gap penalties and weight matrix choice. Nucleic Acids Res 22:4673-4680

Ulysséa MA, Brandão CR (2013) Ant species (Hymenoptera, Formicidae) from the seasonally dry tropical forest of northeastern Brazil: a compilation from field surveys in Bahia and literature records. Rev Bras Entomol 57:217-224

Vasconcelos HL, Delabie JHC (2000) Ground ant communities form central Amazonia forest fragments. In: Agosti D, Majer JD, Alonso LE, Schultz T (eds) Sampling ground-dwelling ants: case studies from world's rain forests, vol 18. Curtin University School of Environmental Biology Bulletin, Perth, pp 59-69

Wheeler WM (1915) On the presence and absence of co-coons among ants, the nest-spinning habits of the larvae and the significance of black cocoons among certain australian species. Ann Entomol Soc Am 8:323-342

Wheeler GC, Wheeler J (1953) The ant larvae of the subfamily Formicinae. Part II. Ann Entomol Soc Am 46:175-217

Yamamoto M, Del-Claro K (2008) Natural history and foraging behavior of the carpenter ant Camponotus sericeiventris Guérin, 1838 (Formicinae, Campotonini) in the Brazilian tropical savanna. Acta Ethol 11:55-65 